\title{
ADAPTASI MUSIMAN NELAYAN TRAMMEL NET DI PELABUHAN PERIKANAN SAMUDERA CILACAP
}

\section{SEASONAL ADAPTATION OF TRAMMEL NET FISHERS IN CILACAP OCEANIC FISHING PORT}

\author{
Agung Nugraha ${ }^{1}$, Prihatin Ika Wahyuningrum ${ }^{2}$, Domu Simbolon ${ }^{2}$ \\ ${ }^{1}$ Program Studi Teknologi dan Manajemen Perikanan Tangkap, \\ ${ }^{2}$ Departemen Pemanfaatan Sumberdaya Perikanan, \\ Fakultas Perikanan dan Ilmu Kelautan, IPB University \\ Korespondensi: piwahyuningrum@apps.ipb.ac.id
}

\begin{abstract}
Fishers, including trammel net fishers, have different respond due to seasonal changes. The research aims to calculate shrimp season index, to identify the impact of seasonal changes related to income of trammel net fishers, and to identify the adaptation pattern of trammel net fishers related to shrimp season changes. The data collected were trammel net fishing unit performance, trammel net fisherman adaptation methods, investment data, income, and fishermen's capital as well as trip data and trammel net shrimp production data for five years (2012-2016). Data analysis used fishing season index, fishing season impact related to income of fishers, and fishers adaptation to seasonal changes. The results showed that there are five months were identified as peak season of shrimp i.e. June, September, October, November, and December. Other results showed that seasonal changes have impacted to trammel net fishers income amounted Rp 6.185.800/vessel/trip. At the peak season fishing, fisher income were Rp 6.591.495/vssel/trip, however at the low season fishers income were Rp 405.695/vessel/trip. In addition there were five adaptation pattern related to seasonal changes of trammel net fishers which were 37\% lending money and selling stuffs, 33\% repairing fishing gear, $13 \%$ fishing gear diversification, $10 \%$ changing the fishing ground, and $7 \%$ income diversification. In conclution that fishers who choose adaptation pattern of fishing gear diversification have the highest income compared to fishers who choose other types of adaptation.
\end{abstract}

Keywords: Cilacap Oceanic Fishing Port, fishers adaptation, shrimp season, trammel net

\begin{abstract}
ABSTRAK
Nelayan memiliki respon yang berbeda dalam menghadapi perubahan musim, termasuk nelayan trammel net di PPS Cilacap. Penelitian ini bertujuan untuk menghitung indeks musim penangkapan udang yang ditangkap menggunakan alat tangkap trammel net, mengindentifikasi dampak perubahan musim terhadap pendapatan nelayan trammel net, dan mengindentifikasi pola adaptasi nelayan trammel net terhadap perubahan musim udang. Data yang dikumpulkan yaitu keragaan unit penangkapan trammel net, cara adaptasi nelayan trammel net, data investasi, penghasilan, dan modal nelayan serta data trip dan data produksi udang hasil tangkapan trammel net selama 5 tahun (2012-2016). Indeks musim penangkapan ikan dihitung menggunakan rata-rata bergerak, analisis pendapatan digunakan untuk menghitung dampak musim penangkapan ikan terhadap pendapatan nelayan, dan analisis deskriptif digunakan untuk melihat adaptasi nelayan terhadap perubahan musim. Hasil penelitian menunjukkan bahwa musim penangkapan udang di PPS Cilacap terjadi selama lima bulan yaitu bulan Juni, September, Oktober, November, dan Desember. Perubahan musim berdampak terhadap penurunan pendapatan nelayan trammel net sebesar Rp 6.185.800/ kapal/trip. Rata-rata pendapatan ketika musim penangkapan udang sebesar Rp 6.591.495/kapal/trip, sedangkan rata-rata pendapatan nelayan ketika tidak musim penangkapan udang sebesar Rp 405.695/kapal/trip. Pola adaptasi nelayan trammel net terhadap perubahan musim penangkapan udang yaitu meminjam uang dan menjual barang-barang sebanyak 37\%, memperbaiki alat tangkap sebanyak 33\%, penganekaragaman alat tangkap sebanyak 13\%, perubahan lokasi DPI sebanyak 10\%, dan penganekaragaman pendapatan sebanyak $7 \%$. Nelayan yang memilih pola adaptasi penganekaragaman alat tangkap diidentifikasi memiliki pendapatan tertinggi dibandingkan dengan nelayan yang memilih opsi adaptasi lainnya.
\end{abstract}

Kata kunci: adaptasi nelayan, musim penangkapan udang, Pelabuhan Perikanan Samudera Cilacap, trammel net 


\section{PENDAHULUAN}

Salah satu sumberdaya yang melimpah di perairan Cilacap adalah udang. Udang tersebut meliputi udang jerbung (Penaeus merguensis), udang dogol (Metapenaeus ensis), udang krosok (Parapenaeopis sculptilis) dengan produksi 63,85 ton, udang barat (Metapenaeus dobsoni), dan udang tiger (Penaeus monodon). Produksi udang tersebut secara berurutan mencapai 130,04 ton, 102,05 ton, 63,85 ton, 0,59 ton, dan 0,27 ton (PPS Cilacap 2016). Sebagian besar nelayan di PPS Cilacap menangkap udang menggunakan alat tangkap trammel net. Waktu yang dibutuhkan untuk pengoperasian alat tangkap ini selama satu hari dalam sekali trip melaut.

Nelayan mencari daerah penangkapan ikan dengan mengandalkan keterampilan dan pengalaman yang dimilikinya. Salah satu faktor yang mempengaruhi operasi penangkapan trammel net kondisi oseanografis perairan yang mempengaruhi musim penangkapan ikan (Priadana et al. 2017). Namun demikian, karena kondisi lingkungan yang tidak teratur menyebabkan masih terdapatnya permasalahan di lapangan seperti kurangnya informasi tentang musim penangkapan ikan dan musim ikan yang berubah-ubah menyebabkan waktu pengoperasian alat tangkap trammel net menjadi terganggu, sehingga diperlukan informasi musim penangkapan ikan bagi nelayan trammel net agar operasi penangkapan dapat berjalan secara efektif dan efisien. Disisi lain, ketergantungan nelayan terhadap kehidupan pesisir dan laut dipengaruhi oleh kondisi alam yang tentunya memberikan pengaruh besar bagi kehidupan nelayan, terutama bagi masyarakat nelayan skala kecil (Satria 2009) termasuk didalamnya yaitu nelayan trammel net di PPS Cilacap. Hal tersebut menjadikan nelayan sering tidak dapat melakukan kegiatan operasi penangkapan ikan karena perubahan musim. Ketika nelayan tidak melakukan operasi penangkapan, nelayan secara tidak langsung akan mengalami permasalahan yaitu penurunan produktivitas dan aktivitas yang pada akhirnya dapat berimbas pada permasalahan menurunnya pendapatan nelayan.

Dampak adanya perubahan musim dapat memunculkan respon dan upaya adaptasi nelayan trammel net. Menurut Helmi dan Satria (2012), adaptasi merupakan suatu perilaku responsif yang memungkinkan manusia untuk dapat menyesuaikan diri dengan kondisi perubahan lingkungan yang ada. Adaptasi yang dilakukan oleh nelayan memungkinkan nelayan untuk mengatur persoalan-persoalan yang ada seperti penurunan pendapatan nelayan. Nelayan di Dusun Ciawitali, Kabupaten Ciamis melakukan berbagai macam bentuk adaptasi karena perubahan iklim. Adaptasi tersebut antara lain: "mengejar musim ikan", adaptasi sumberdaya pesisir untuk menghasilkan komoditas ekonomi tanpa melaut, alokasi sumberdaya dalam rumah tangga yang meliputi optimalisasi tenaga kerja dalam rumah tangga dan pola nafkah ganda, dan tidak lagi bekerja pada sektor perikanan (Patriana dan Satria 2013). Nugraheni (2015) menyatakan bahwa pola adaptasi nelayan antara lain dengan mengurangi hari trip, tidak mencari penghasilan, berganti profesi, dan menganggur. Sedangkan Rahmah (2016), menyatakan pola adaptasi yang biasa dilakukan nelayan yaitu mengurangi jumlah trip, menganggur, memperbaiki alat tangkap, dan mengganti alat tangkap.

Nelayan perlu melihat opsi-opsi adaptasi yang dilakukan oleh mereka dan menilai opsi adaptasi apa yang paling baik untuk dilakukan terutama dari sisi ekonomi. Manfaat adanya upaya adaptasi nelayan yakni untuk menyelamatkan perekonomian nelayan dan ekosistem pesisir dengan suatu cara pemanfaatan yang berkelanjutan (Lekatompessy et al. 2013).

Penelitian ini bertujuan untuk menghitung indeks musim penangkapan udang yang ditangkap menggunakan alat tangkap trammel net, mengindentifikasi dampak perubahan musim terhadap pendapatan nelayan trammel net, dan mengindentifikasi pola adaptasi nelayan trammel net terhadap perubahan musim.

\section{METODE PENELITIAN}

\section{Tempat dan waktu penelitian}

Penelitian dilakukan di Pelabuhan Perikanan Samudera (PPS) Cilacap, Jawa Tengah pada bulan Maret-April 2017.

\section{Alat dan bahan}

Penelitian ini menggunakan kuesioner untuk proses wawancara kepada 
nelayan mengenai: trip perbulan, investasi, penerimaan, keuntungan nelayan, dan pola adaptasi nelayan menghadapi perubahan musim. Kamera digunakan untuk dokumentasi. Serta Software Microsoft Excel 2013 untuk pengolahan data, menghitung nilai indeks musim penangkapan (IMP), dan pola adaptasi nelayan.

\section{Metode pengumpalan data, jenis dan sumber data}

Metode survei digunakan dalam pengumpulan data pada penelitian ini. Jenis data pada penelitian ini dikelompokan menjadi dua, yakni data primer dan data sekunder. Data primer didapatkan dari hasil wawancara langsung kepada nelayan yang menggunakan alat tangkap trammel net di PPS Cilacap. Data yang dikumpulkan antara lain adalah keragaan unit penangkapan trammel net, cara adaptasi nelayan trammel net, data investasi, penghasilan, dan modal nelayan. Cara adaptasi nelayan merupakan pertanyaan tertutup berdasarkan hasil wawancara dengan nelayan pada survey pra penelitian. Sedangkan data sekunder antara lain data trip dan data produksi udang hasil tangkapan trammel net dari bulan Januari 2012-Desember 2016.

Data responden dikumpulkan dengan teknik accidental sampling melalui pertimbangan karakteristik sampel yakni kapal beroperasi di perairan Cilacap, nelayan menggunakan alat tangkap trammel net, dan sampel nelayan terpilih dapat mewakili seluruh unit penangkapan trammel net.
Umar (2004) mengatakan bahwa ukuran minimum sampel yang dapat diterima agar memperoleh informasi yang baik minimal berjumlah $10 \%$ dari populasi. Jumlah sampel yang diambil dalam penelitian ini sebanyak 30 unit penangkapan trammel net dari total 110 unit nelayan trammel net. Jenis data yang diambil pada penelitian ini disajikan pada Tabel 1 .

\section{Analisis data}

\section{Musim penangkapan ikan}

Informasi mengenai musim penangkapan ikan dapat dianalisis dengan menggunakan analisis Indeks Musim Penangkapan (IMP). Nilai tersebut diperoleh dengan menghitung data produksi hasil tangkapan udang dan effort selama 5 tahun berturut-turut (tahun 2012-2016). Nilai indeks musim penangkapan dinyatakan dalam satuan persen (\%). Keuntungan menggunakan indeks musim penangkapan yakni dapat mengisolasi fluktuasi musiman, menghilangkan kecenderungan pada deret waktu (time series), dan menentukan saat yang tepat untuk musim penangkapan ikan. Penentuan Indeks Musim Penangkapan (IMP) dengan menggunakan rasio rata-rata bergerak (moving average). Kriteria Indeks Musim Penangkapan (IMP) digolongkan dalam dua kategori yaitu: musim ikan dan tidak musim ikan (Syahrir et al. 2010). Penggolongan musim penangkapan ikan disajikan pada Tabel 2 .

Tabel 1. Tujuan, data, teknik pengumpulan, dan sumber data

\begin{tabular}{|c|c|c|c|}
\hline Tujuan & Data & $\begin{array}{c}\text { Teknik } \\
\text { pengumpulan }\end{array}$ & Sumber data \\
\hline $\begin{array}{l}\text { - Menghitung indeks } \\
\text { musim penangkapan } \\
\text { udang yang ditangkap } \\
\text { alat tangkap trammel net }\end{array}$ & $\begin{array}{l}\text { Trip dan produksi udang } \\
\text { perbulan dari Januari } \\
\text { 2012-Desember } 2016 \text {. }\end{array}$ & Studi literatur & PPS Cilacap \\
\hline $\begin{array}{l}\text { - Mengindentifikasi } \\
\text { dampak perubahan } \\
\text { musim terhadap } \\
\text { pendapatan nelayan } \\
\text { trammel net }\end{array}$ & $\begin{array}{l}\text { Investasi, penghasilan, } \\
\text { dan modal usaha masing- } \\
\text { masing unit penangkapan } \\
\text { trammel net }\end{array}$ & $\begin{array}{l}\text { Wawancara dan } \\
\text { kuesioner }\end{array}$ & Nelayan \\
\hline $\begin{array}{l}\text { - Mengindentifikasi } \\
\text { pola adaptasi nelayan } \\
\text { trammel net terhadap } \\
\text { perubahan musim }\end{array}$ & $\begin{array}{l}\text { Cara adaptasi nelayan } \\
\text { trammel net }\end{array}$ & $\begin{array}{c}\text { Wawancara dan } \\
\text { kuesioner }\end{array}$ & Nelayan \\
\hline
\end{tabular}


Tabel 2. Penggolongan musim penangkapan

\begin{tabular}{lcc}
\hline No & Nilai IMP & Kategori musim \\
\hline 1 & $<100 \%$ & Tidak musim ikan \\
2 & $\geq 100 \%$ & Musim ikan \\
\hline
\end{tabular}

Sumber: Syahrir et al. (2010)

Dampak perubahan musim terhadap pendapatan nelayan

Dampak perubahan musim terhadap pendapatan nelayan dianalisis secara sederhana yaitu menghitung total penerimaan hasil produksi dikurangi dengan biaya penangkapan selama kegiatan operasi penangkapan. Pendapatan nelayan diperoleh dari bagi hasil yang disepakati antara pemilik kapal, nakhoda, dan ABK. Secara matematis pendapatan (keuntungan) dapat dirumuskan sebagai berikut (Pratama 2012):

$$
\pi=T R-T C
$$

Keterangan:

$\pi \quad$ : Pendapatan (keuntungan) (Rp/trip)

$T R$ : (Total penerimaan)

$T C$ : (Total biaya)

Analisis ini bertujuan melihat pengaruh perubahan musim terhadap pendapatan yang diperoleh nelayan dalam melakukan operasi penangkapan ikan dengan melihat perubahan pendapatan ketika musim ikan dan ketika tidak musim ikan. Hasil perhitungan berdasarkan data rata-rata yang diperoleh dari nelayan.

Adaptasi nelayan terhadap perubahan musim

Adaptasi nelayan terhadap perubahan musim dianalisis secara deskriptif. Analisis ini dimaksudkan untuk mengetahui pola adaptasi nelayan trammel net dalam memenuhi kebutuhan hidupnya. Pola adaptasi nelayan diantaranya dengan mengurangi hari trip, tidak mencari penghasilan, berganti profesi, dan menganggur (Nugraheni 2015). Sedangkan Rahmah (2016), menyatakan pola adaptasi yang biasa dilakukan nelayan yaitu mengurangi jumlah trip, menganggur, memperbaiki alat tangkap, dan mengganti alat tangkap. Berdasarkan dua referensi di atas dan disesuaikan dengan kondisi di lapangan, pola adaptasi nelayan trammel net diklasifikasikan menjadi meminjamuang dan menjual barang-barang, memperbaiki alat tangkap, penganekaragaman alat tangkap, perubahan lokasi Daerah Penangkapan Ikan (DPI), dan penganekaragaman pendapatan.

\section{HASIL DAN PEMBAHASAN}

\section{Musim penangkapan udang}

Musim penangkapan adalah kurun waktu tertentu ada tidaknya hasil tangkapan pada proses penangkapan ikan (Febrianto et al. 2017). Berdasarkan perhitungan nilai indeks musim penangkapan, musim penangkapan udang di PPS Cilacap dibagi menjadi dua kategori, yaitu musim udang dan tidak musim udang. Musim penangkapan dikategorikan musim udang jika nilai IMP pada bulan tertentu $\geq 100 \%$ dan dikategorikan tidak musim musim udang jika nilai IMP $<100 \%$. Grafik indeks musim penangkapan disajikan pada Gambar 1.

Secara umum terdapat empat kelompok musim berdasarkan arah angin yang melewati Indonesia yaitu musim barat (Desember, Januari, Februari), musim peralihan satu (Maret, April, Mei), musim timur (Juni, Juli, Agustus), dan musim peralihan dua (September, Oktober, November) (Febrianto et al. 2017). Grafik indeks musim penangkapan udang (Gambar 1) menunjukkan bahwa musim penangkapan udang terjadi selama lima bulan yaitu pada bulan Juni (musim timur), bulan September, Oktober, November (musim peralihan II), dan bulan Desember (musim barat). Sedangkan kondisi tidak musim penangkapan udang terjadi selama tujuh bulan yaitu pada bulan Januari dan Februari (musim barat), Maret, April, dan Mei (musim peralihan I), Juli dan Agustus (musim timur). Hasil yang didapat sesuai dengan penelitian Miftahudin (2016), yang menginformasikan bahwa musim penangkapan udang dogol di perairan Cilacap terjadi pada bulan September (musim peralihan II). Hal ini juga sejalan dengan penelitian Hartani (2006), yang menginformasikan bahwa musim puncak 
penangkapan udang jerbung di perairan Pangandaran terjadi pada bulan November (musim peralihan II). Menurut Wiyono (2001), setidaknya terdapat dua faktor yang mempengaruhi perubahan musim penangkapan. Faktor pertama adalah ruaya ikan atau udang (baik untuk kepentingan makan, pembesaran, proses produksi, dan berubahnya lingkungan perairan akibat perbuatan manusia), dan faktor kedua adalah berubahnya kondisi lingkungan perairan itu sendiri (baik secara meteorologi maupun oseanografi).

Hasil pada Gambar 1 menunjukkan adanya penurunan nilai IMP pada musim barat. Berdasarkan hasil wawancara terjadinya penurunan nilai IMP pada musim barat bisa disebabkan oleh cuaca tidak menentu sehingga berakibat terjadi penurunan upaya penangkapan oleh nelayan. Hal tersebut diperkuat oleh penelitian Pariwono (1996), yang menyatakan bahwa secara umum terjadi penurunan stok ikan di wilayah selatan Jawa pada triwulan pertama yaitu pada bulan Januari-Maret disebabkan terjadinya perubahan Suhu Permukaan Laut (SPL) dan tekanan udara permukaan laut di daerah tangkapan. Lebih lanjut, Hartani (2006), menyatakan bahwa musim barat merupakan masa paceklik ikan, hal ini karena diduga terjadinya gelombang besar, angin kencang, dan kondisi perairan yang tidak tenang. Sehingga dengan kondisi tersebut menyebabkan nelayan trammel net tidak berani mengambil resiko untuk melakukan operasi penangkapan ikan, apabila kondisi perairan sudah membaik maka nelayan baru berani untuk melakukan operasi penangkapan ikan. Terkait dengan kelimpahan ikan secara temporal, terdapat variasi kondisi lingkungan yang menyebabkan perubahan kelimpahan ikan (Sachoemar el al. 2012).

\section{Pendapatan nelayan}

Musim penangkapan udang yang berubah dapat berpengaruh terhadap jumlah hasil tangkapan yang pada akhirnya dapat berimbas pada besarnya pendapatan nelayan. Pendapatan nelayan dipengaruhi oleh modal usaha dan penerimaan setelah operasi penangkapan ikan. Modal usaha merupakan salah satu hal yang sangat penting dalam kegiatan operasi penangkapan udang oleh nelayan trammel net. Berdasarkan hasil wawancara terhadap nelayan trammel net, beberapa modal usaha pokok dalam unit penangkapan trammel net yaitu kapal, alat tangkap, mesin, BBM, dan perbekalan nelayan. Adanya modal usaha dalam operasi penangkapan dapat memberikan kemudahan dalam usaha penangkapan ikan, serta sebagai sarana nelayan untuk mencari ikan di laut. Besarnya modal usaha yang digunakan dalam kegiatan operasi penangkapan ikan dapat menentukan keberhasilan hasil tangkapan nelayan (Jamal 2013). Hasil tangkapan yang diperoleh nelayan trammel net kemudian digunakan untuk menentukan pendapatan nelayan trammel net di PPS Cilacap. Pendapatan nelayan trammel net dibagi menjadi dua kategori yaitu pendapatan ketika musim udang dan tidak musim udang. Berdasarkan hasil wawancara nelayan diperoleh pendapatan untuk satu kali trip penangkapan ketika musim udang sebesar Rp 6.591.495/kapal/ trip, sedangkan pendapatan ketika tidak musim udang sebesar Rp 405.695/kapal/ trip. Selengkapnya pendapatan nelayan trammel net per trip di PPS Cilacap disajikan pada Tabel 3.

Sistem bagi hasil nelayan trammel net di PPS Cilacap dihitung berdasarkan pendapatan/keutungan yang diperoleh pada Tabel 3 yang dimasukkan ke dalam sistem bagi hasil. Sistem bagi hasil merupakan kesepakatan antara pemilik kapal, nakhoda, dan ABK nelayan trammel net. Pemilik kapal mendapatkan keuntungan sebesar 50\% dari total pendapatan bersih dan keutungan $50 \%$ sisanya untuk nakhoda dan ABK. Sedangkan untuk sistem bagi hasil antara nakhoda dan ABK, nakhoda mendapatkan dua bagian dan ABK mendapatkan satu bagian. Berdasarkan hasil wawancara terhadap nelayan trammel net diperoleh bagi hasil ketika musim udang untuk pemilik kapal Rp 3.295.748/trip, nakhoda Rp 1.098.802/trip, dan setiap ABK Rp $549.236 /$ trip. Sedangkan bagi hasil ketika tidak musim udang untuk pemilik kapal Rp 202.848/trip, nakhoda Rp 67.629/trip, dan setiap ABK Rp 33.805/trip (Tabel 4). Sistem bagi hasil nelayan trammel net per trip di PPS Cilacap disajikan pada Tabel 4. 


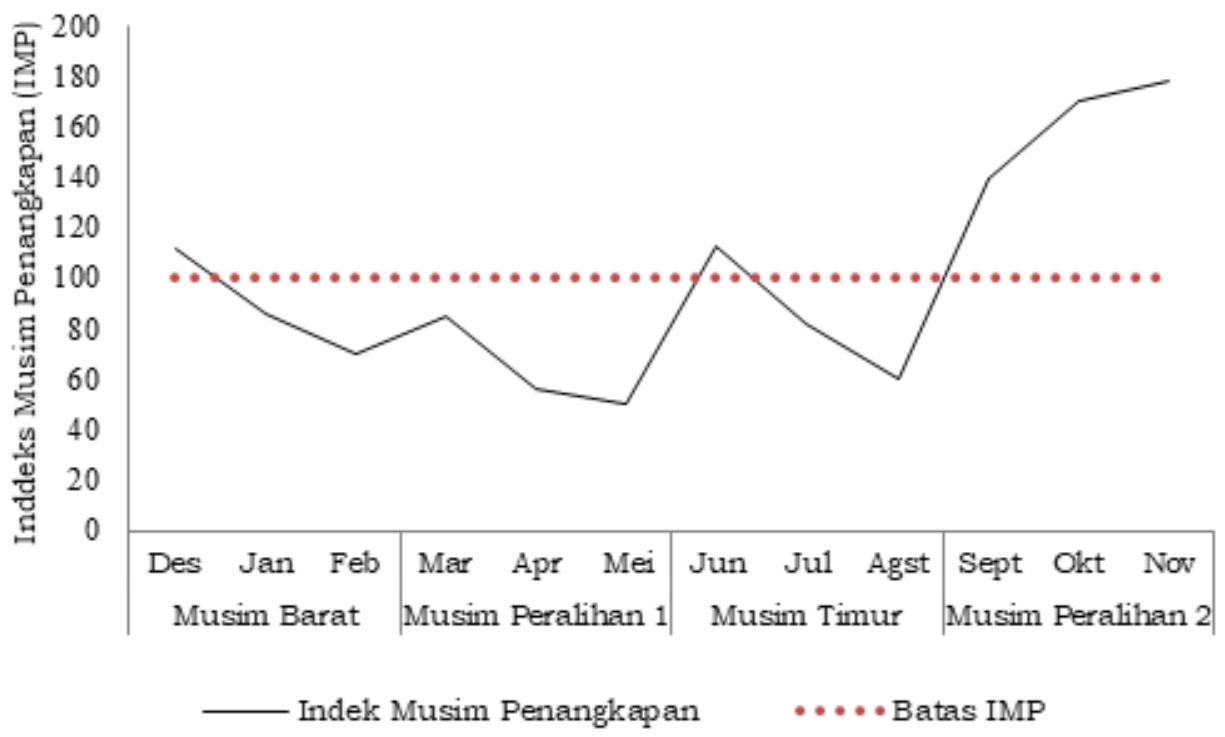

Gambar 1. Grafik Indeks Musim Penangkapan (IMP)

Tabel 3. Pendapatan nelayan trammel net per trip di PPS Cilacap

\begin{tabular}{lrr}
\hline \multicolumn{1}{c}{ Investasi } & Unit & \multicolumn{1}{c}{ Jumlah (Rp) } \\
\hline Kapal & 1 Unit & 100.000 .000 \\
Mesin utama & 1 Unit & 30.000 .000 \\
Jaring trammel net & 30 piece & 13.800 .000 \\
Total investasi & & 143.800 .000 \\
\hline & Musim udang (kapal/trip) & Tidak musim udang (kapal/trip) \\
\hline Biaya Tetap & 445.255 & 445.255 \\
Biaya Variabel & 1.095 .750 & 870.550 \\
Total Biaya (TC) & 1.541 .005 & 1.315 .805 \\
Total Penerimaan (TR) & 8.132 .500 & 1.721 .500 \\
Pendapatan (r) & $\mathbf{6 . 5 9 1 . 4 9 5}$ & $\mathbf{4 0 5 . 6 9 5}$ \\
\hline
\end{tabular}

Tabel 4. Bagi hasil nelayan trammel net per trip di PPS Cilacap

\begin{tabular}{lrr}
\hline \multicolumn{1}{c}{ Bagi hasil } & Musim udang (Rp/trip) & Tidak musim udang (Rp/trip) \\
\hline Pemilik & 3.295 .748 & 202.848 \\
Nahkoda & 1.098 .802 & 67.629 \\
ABK & 549.236 & 33.805 \\
\hline
\end{tabular}

Pendapatan bulanan nelayan trammel net di PPS Cilacap diperoleh dari perhitungan pendapatan bagi hasil dikalikan dengan jumlah trip setiap bulan. Jumlah trip/bulan ketika musim udang berkisar \pm 17 trip/bulan dan ketika tidak musim udang beriksar \pm 8 trip/bulan. Selanjutnya, pendapatan bulanan nelayan trammel net dibandingkan dengan Upah Minimum Kabupaten (UMK) Cilacap tahun 2018 sebesar Rp 1.841.209 (Kepgub Nomer 560/94 2017). Berdasarkan data hasil wawancara dapat dilihat bahwa pendapatan bulanan nelayan trammel net di PPS Cilacap ketika musim udang untuk pemilik, nakhoda, dan ABK lebih besar dari UMK Cilacap, sedangkan pendapatan bulanan nelayan trammel net ketika tidak musim udang untuk pemilik, nakhoda, dan ABK lebih kecil dari UMK Cilacap (Tabel 5). Secara keseluruhan pendapatan bulanan nelayan trammel net di PPS Cilacap disajikan pada Tabel 5.

Penyebab terjadinya perbedaan pendapatan yang diperoleh nelayan ketika musim udang dan tidak musim udang 
dikarenakan adanya perubahan musim ikan yang mengakibatkan berkurangnya upaya penangkapan dan hari melaut sehingga berakibat berkurangnya hasil tangkapan udang. Priadana et al. (2017) mengatakan bahwa pendapatan nelayan yang berbeda tidak terlepas dari beberapa hal seperti hasil tangkapan yang diperoleh, musim ikan, dan jugafaktorkeberhasilanusahapenangkapan. Walaupun pendapatan nelayan trammel net yang diperoleh ketika tidak musim udang lebih rendah dari pendapatan ketika musim udang, nelayan trammel net yang ada di PPS Cilacap tetap mempertahankan usaha penangkapan udang sebagai usaha utama dalam memenuhi kebutuhan hidup baik ketika musim udang maupun ketika tidak musim udang. Kegiatan menangkap ikan merupakan satu-satunya kegiatan ekonomi yang selama ini diandalkan oleh nelayan untuk dapat memenuhi kebutuhan keluarganya (Wiyono 2008). Nelayan trammel net mempunyai kecenderungan untuk tetap melakukan usaha penangkapan ikan dan memilih membagi resiko kerugiannya secara bersama-sama. Pilihan ini diambil karena beberapa alasan. Pertama adalah terbatasnya pendidikan nelayan trammel net. Kedua adalah terbatasnya keterampilan dan keahlian yang dimiliki oleh nelayan trammel net, sedangkan kebutuhan untuk keluarga nelayan harus tetap terpenuhi.

\section{Adaptasi nelayan}

Perubahan adaptasi nelayan trammel net yang terjadi di PPS Cilacap sangat dipengaruhi oleh adanya perubahan musim penangkapan udang. Adanya perubahan musim menjadikan nelayan beradaptasi terhadap perubahan lingkungan untuk memenuhi kebutuhan keluarganya. Hasil penelitian menunjukkan bahwa terdapat lima jenis pola adaptasi nelayan trammel net di PPS terhadap perubahan musim agar dapat memenuhi kebutuhan keluarga nelayan, yaitu meminjam uang dan menjual barang-barang, memperbaiki alat tangkap, penganekaragaman alat tangkap, perubahan lokasi Daerah Penangkapan Ikan (DPI), dan penganekaragaman pendapatan. Pola adaptasi nelayan terhadap perubahan musim disajikan pada Gambar 2.

Jenis adaptasi pertama adalah meminjam uang dan menjual barang-barang. Berdasarkan hasil wawancara terhadap nelayan, sebanyak $37 \%$ dari responden nelayan menyatakan mereka memilih untuk meminjam uang dan menjual barang yang dimiliki ketika terjadi perubahan musim. Nelayan memilih adaptasi ini karena nelayan tidak bisa beradaptasi ketika perubahan musim. Setidaknya terdapat dua faktor yang menyebabkan nelayan tidak bisa beradaptasi terhadap perubahan musim. Faktor pertama adalah nelayan sangat bergantung terhadap kegiatan penangkapan ikan dan faktor kedua nelayan tidak memiliki keahlian lain. Hal tersebut menyebabkan ketika tidak musim udang, nelayan memilih untuk tidak melakukan kegiatan operasi penangkapan udang. Waktu nelayan yang tersisa dihabiskan dengan berkumpul bersama keluarga sampai kondisi musim mulai membaik dan nelayan dapat kembali melakukan operasi penangkapan udang. Untuk memenuhi kebutuhan sehari-hari ketika tidak musim udang, nelayan akan menjual barang-barang yang dimiliki dan meminjam uang kepada tengkulak atau pemilik kapal. Sebagai jaminannya ketika musim udang, nelayan akan menjaminkan hasil tangkapannya kepada tengkulak atau pemilik kapal. Nelayan trammel net pada kondisi ini tidak rekomendasikan untuk meminjam uang, hal ini karena dapat berdampak pada meningkatnya biaya pengeluaran nelayan. Nelayan trammel net lebih baik dapat menyimpan keuntungan hasil tangkapan dalam bentuk tabungan, sehingga dapat digunakan dalam kondisi ketika tidak musim udang.

Tabel 5. Pendapatan bulanan untuk pemilik, nakhoda, dan ABK

\begin{tabular}{lrr}
\hline Pendapatan/bulan & Musim udang (Rp/bulan) & Tidak musim udang (Rp/bulan) \\
\hline Pemilik & 56.027 .708 & 1.622 .780 \\
Nakhoda & 18.679 .638 & 541.035 \\
ABK & 9.337 .017 & 270.436 \\
\hline
\end{tabular}




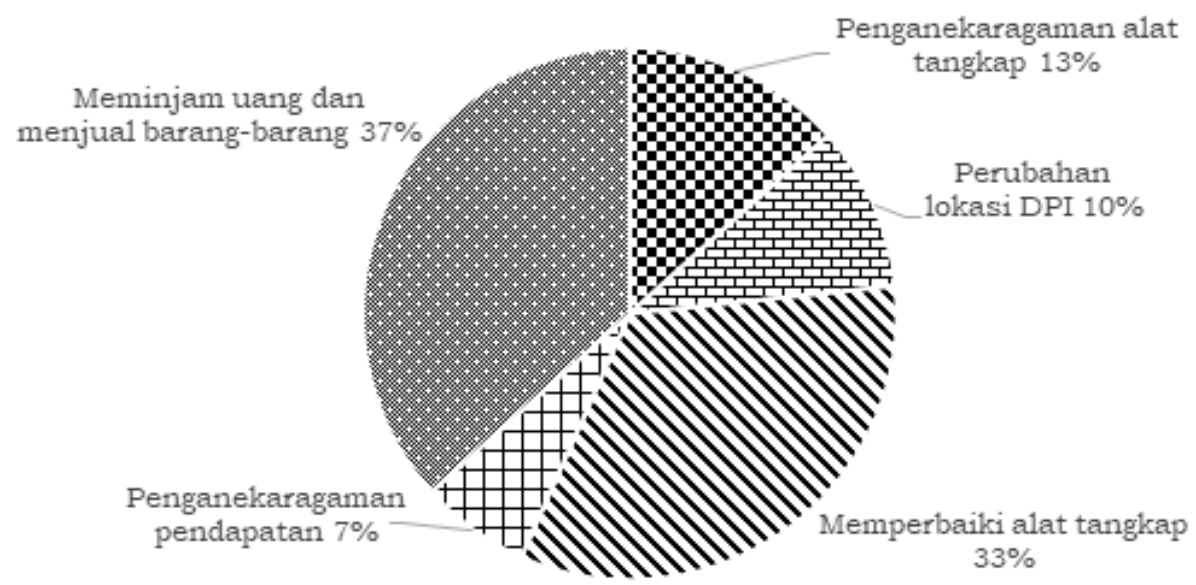

Gambar 2. Pola adaptasi nelayan terhadap perubahan musim

Jenis adaptasi kedua adalah memperbaiki alat tangkap. Berdasarkan hasil wawancara terhadap nelayan, sebanyak $33 \%$ dari responden nelayan memilih jenis adaptasi ini. Dengan alasan untuk menghemat biaya perbaikan alat tangkap, selain itu juga untuk mempersiapkan alat tangkap dalam operasi penangkapan ikan selanjutnya ketika musim udang mulai kembali membaik, sehingga alat tangkap dapat beroperasi secara maksimal. Dalam hal ini, modal untuk memberbaiki alat tangkap berasal dari pemilik kapal. Sedangkan untuk memenuhi kebutuhan pokok sehari-hari. Nelayan hanya mengandalkan pinjaman uang dari tengkulak atau pemilik kapal.

$$
\text { Jenis adaptasi ketiga adalah }
$$
penganekaragaman alat tangkap. Berdasarkan hasil wawancara terhadap nelayan, sebanyak 13\% dari responden nelayan memilih adaptasi ini. Nelayan memilih penganekaragaman alat tangkap gillnet dengan tipe jaring nilon, jaring dua inch, atau jaring lima inch karena mudah untuk digunakan. Adaptasi ini dipilih oleh nelayan di Cilacap untuk menyesuaikan dengan musim ikan yang paling banyak ada di perairan Cilacap dan saat alat tangkap trammel net tidak memungkinkan untuk dioperasikan. Selain itu, berbagai jenis udang sebagai tangkapan utama di perairan Cilacap sudah jauh berkurang, sehingga nelayan tidak hanya terfokus untuk menangkap udang tetapi mereka juga menangkap jenis ikan lain. Kondisi ini menyebabkan jenis alat tangkap yang digunakan nelayan semakin bertambah. Sebelumnya nelayan hanya memiliki satu alat tangkap, namun sekarang nelayan bisa memiliki dua sampai tiga alat tangkap. Faktor yang menyebabkan tidak semua nelayan memilih adaptasi ini adalah keterbatasan modal nelayan dan keterampilan nelayan.
Jenis adaptasi keempat adalah perubahan lokasi Daerah Penangkapan Ikan (DPI). Perubahan daerah penangkapan ini terjadi karena ada perubahan ekologis yaitu adanya akumulasi endapan dan cemaran limbah industri yang terjadi di sekitar sagara anakan Cilacap (Mustaruddin et al. 2016). Menurut Helmi dan Satria (2012), kondisi lingkungan sekitar pesisir yang mengalami perubahan ekologis bisa merubah daerah penangkapan ikan (fishing ground) menjadi lebih jauh. Lebih lanjut, menurut Manoppo et al. (2012), faktor yang mendorong nelayan untuk berpindah lokasi penangkapan yaitu pendapatan yang tidak pasti, persediaan ikan menurun, dan modal usaha terbatas. Namun tidak semua nelayan memilih adaptasi ini karena keterbatasan ukuran kapal sehingga nelayan tidak dapat menjangkau lokasi daerah penangkapan ikan yang dituju. Berdasarkan hasil wawancara terhadap nelayan, sebanyak 10\% dari responden nelayan memilih perubahan lokasi daerah penangkapan ikan. Adapun pola dari adaptasi ini adalah kegiatan mengubah lokasi sesuai musim ikan. Hasil wawancara menyebutkan ketika terjadi musim timuroje maka daerah yang dituju adalah daerah Gombong, Kebumen, dan Parangtritis, sebaliknya jika terjadi musim barat, maka daerah yang dituju adalah daerah Pangandaran, Cikaso Sukabumi, dan Batukaras.

Jenis adaptasi kelima adalah memilih penganekaragaman pendapatan. Penganekaragaman pendapatan dipilih untuk memperkecil resiko dan kelemahan nelayan (Allison dan Ellis 2001 dalam Helmi dan Satria 2012). Berdasarkan hasil wawancara terhadap nelayan, sebanyak 7\% dari responden nelayan memilih adaptasi penganekaragaman pendapatan dengan beralih profesi menjadi buruh perusahaan, 
buruh bangunan, dan tukang ojek. Nelayan memilih berganti pekerjaan untuk mengurangi resiko ketika kondisi tidak musim udang. Faktor yang mendorong nelayan melakukan penganekaragaman pendapatan yaitu pengalaman melaut, tanggungan keluarga, pendapatan nelayan tidak pasti, dan pesediaan ikan menurun (Manoppo et al. 2012). Menurut Ellis (1998) dalam Helmi dan Satria (2012), penganekaragaman pendapatan merupakan atribut yang penting bagi masyarakat di pedesaan di negara-negara berkembang. Lebih lanjut Allison dan Ellis (2001) dalam Helmi dan Satria (2012), menyatakan bahwa penganekaragaman pendapatan merupakan pilihan rasional ditengah tingginya resiko nelayan dalam menghadapi fluktuasi musim ikan. Alasan nelayan memilih penganekaragaman pendapatan karena berkerja sebagai buruh perusahaan, buruh bangunan dan tukang ojek tidak memerlukan keahlian khusus.

Peran istri dan anak nelayan dalam memenuhi kebutuhan dasar kehidupan ketika tidak musim udang adalah dengan adanya mobilisasi rumah tangga. Menurut Kusnadi (2000), mobilisasi rumah tangga nelayan adalah kegiatan mengikutsertakan anggota rumah tangga nelayan untuk bekerja baik di sektor perikanan maupun diluar sektor perikanan. Lebih lanjut Helmi dan Satria (2012) mengungkapkan bahwa peran istri nelayan dalam memenuhi kebutuhan rumah tangga cukup dominan. Istri nelayan berperan mengatur pengeluaran rumah tangga sehari-hari berdasarkan tingkat penghasilan yang diperoleh dan bukan berdasarkan kebutuhan konsumsi rumah tangga. Menurut Manoppo et al. (2012), faktor yang mendorong nelayan melakukan mobilitas keluarga yaitu kurangnya pengalaman kerja, pendapatan nelayan tidak menentu, persediaan sumberdaya ikan tidak pasti, dan modal usaha yang terbatas.

Jenis pekerjaan yang dimasuki oleh istri-istri nelayan trammel net adalah pengolahan hasil ikan, asisten rumah tangga, dan bekerja pada industri perikanan. Beberapa istri nelayan ada juga yang mendirikan kios kecil yang menyediakan sembako dan jajanan anak-anak. Selain istri nelayan, anak-anak nelayan juga terlibat dalam beberapa pekerjaan untuk memperoleh penghasilan. Contohnya, anak laki-laki membantu orang tuanya dalam operasi penangkapan ikan sedangkan anak perempuan membantu kegiatan rumah tangga dan membantu kegiatan ibunya. Menurut Helmi dan Satria (2012), kegiatankegiatan ekonomi tambahan yang dilakukan oleh anggota rumah tangga nelayan (istri dan anak) merupakan salah satu jenis adaptasi lain yang ditempuh untuk menjaga kelangsungan hidup ditengah ketidakpastian sumberdaya perikanan. Penghasilan yang didapat istri dan anak digunakan untuk menambah keuangan rumah tangga, karena pendapatan yang diperoleh kepala keluarga terkadang tidak cukup untuk memenuhi kebutuhan hidup sehari-hari.

Pendapatan nelayan dalam satu kali trip operasional penangkapan udang terhadap masing-masing pola adaptasi nelayan dapat menunjukkan kemampuan nelayan dalam menghadapi perubahan musim. Pendapatan pada masing-masing pola adaptasi diperoleh dari hasil wawancara terhadap nelayan trammel net di PPS Cilacap dengan melihat jenis pola adaptasi nelayan dalam menghadapi perubahan musim. Berikut ini pendapatan untuk setiap pola adaptasi nelayan trammel net di PPS Cilacap (Tabel 6).

Hasil penelitian (Tabel 6) menunjukkan bahwa pola adaptasi penganekaragaman alat tangkap merupakan salah satu pola adaptasi yang memperoleh pendapatan rata-rata paling tinggi ketika terjadi musim udang. Sehingga nelayan yang memilih pola adaptasi penganekaragaman alat tangkap memiliki pendapatan tertinggi dibandingkan dengan nelayan yang memilih jenis pola adaptasi lainya. Hal ini karena nelayan trammel net melakukan penganekaragaman alat tangkap lain seperti alat tangkap berjenis gillnet dengan bertipe jaring nilon, jaring dua inch, atau jaring lima inch. Hasil tangkapan yang didapat oleh nelayan dengan penganekaragaman alat tangkap ini menjadi lebih banyak. Sedangkan perubahan lokasi daerah penangkapan ikan adalah pola adaptasi yang memperoleh pendapatan rata-rata terendah, baik ketika musim udang, maupun ketika tidak musim udang. Hal ini karena untuk melakukan perubahan lokasi daerah penangkapan ikan, nelayan trammel net memerlukan kapal, dan modal usaha yang lebih besar untuk mencapai fishing ground yang dituju, namun adanya ketidakpastian dalam sumberdaya ikan dapat menyebabkan hasil tangkapan yang diperoleh belum tentu dapat menjanjikan keuntungan lebih bagi nelayan. 
Tabel 6. Pendapatan setiap pola adaptasi nelayan trammel net di PPS Cilacap

\begin{tabular}{lrrrr}
\hline \multirow{2}{*}{ Pola Adaptasi } & \multicolumn{2}{c}{ Rentang pendapatan (Rp/trip) } & \multicolumn{2}{c}{ Rata-rata (Rp/trip) } \\
\cline { 2 - 5 } & Musim udang & $\begin{array}{c}\text { Tidak musim } \\
\text { udang }\end{array}$ & Musim udang & $\begin{array}{c}\text { Tidak musim } \\
\text { udang }\end{array}$ \\
\hline Meminjam uang & $10.861 .000-$ & $1.989 .500-$ & 5.794 .227 & 717.818 \\
dan menjual barang & 1.990 .000 & 467.000 & & \\
Memperbaiki alat & $18.261 .000-$ & $2.523 .000-$ & 8.620 .300 & 1.012 .825 \\
tangkap & 1.369 .000 & 74.000 & & \\
Penganekaragaman & $16.039 .000-$ & $1.104 .500-$ & 9.468 .375 & 763.000 \\
alat tangkap & 2.605 .500 & 469.000 & & \\
Perubahan lokasi & $4.931 .000-$ & $856.000-$ & 3.998 .667 & 604.083 \\
DPI & 3.465 .000 & 180.750 & & \\
Penganekaramanan & $7.807 .000-$ & $1.504 .000-$ & 5.728 .500 & 1.164 .625 \\
pendapatan & 3.650 .000 & 825.250 & & \\
\hline
\end{tabular}

\section{KESIMPULAN DAN SARAN}

\section{Kesimpulan}

1) Musim udang di PPS Cilacap terjadi selama lima bulan yaitu bulan Juni, September, Oktober, November, dan Desember.

2) Perubahan musim berdampak terhadap penurunan pendapatan nelayan trammel net rata-rata sebesar $\mathrm{Rp} 6.185 .800 /$ kapal/trip.

3) Pola adaptasi nelayan trammel net di PPS Cilacap terhadap perubahan musim yaitu meminjam uang dan menjual barang-barang sebanyak 37\%, memperbaiki alat tangkap sebanyak $33 \%$, penganekaragaman alat tangkap sebanyak $13 \%$, perubahan jarak daerah penangkapan ikan sebanyak 10\%, dan penganekaragaman pendapatan sebanyak $7 \%$. Nelayan yang memilih pola adaptasi penganekaragaman alat tangkap memiliki pendapatan tertinggi dibandingkan dengan nelayan yang memilih pola adaptasi lainya.

\section{Saran}

1) Perlu dilakukan penelitian lanjutan mengenai perubahan musim penangkapan udang dengan penambahan parameter-parameter oseanografi.

2) Pemerintah daerah perlu mengadakan kegiatan-kegiatan pelatihan keterampilan bagi nelayan untuk menambah kemampuan nelayan, seperti pelatihan dalam mengolah hasil tangkapan menjadi olahan ikan.

\section{DAFTAR PUSTAKA}

Febrianto A, Simbolon D, Haluan J, Mustaruddin. 2017. Pola Musim Penangkapan Ikan Cumi-Cumi di Perairan Luar dan Dalam Daerah Penambangan Timah Kabuapten Bangka Selatan. Mar Fish. 8(1): 6371.

Hartani TT. 2006. Analisis Pola Musim Penangkapan dan Tingkat Pemanfaatan Udang Jerbung (Panaeus merguiensis de Man) di Perairan Pangandaran Jawa Barat [Skripsi]. Bogor: Institut Pertanian Bogor.

Helmi A, Satria A. 2012. Strategi Adaptasi Nelayan terhadap Perubahan Ekologis. J. Makara, Sosial Humaniora. 16(1): 68-78.

Jamal B. 2013. Analisis Faktor-Faktor yang Mempengaruhi Pendapatan Nelayan (Studi Nelayan Desa Klampis, Kec. Klampis, Ka Bangkalan). J. Ilmiah Mahasiswa FEB Universitas Brawijaya. 2(2): 1-17.

[Kepgub] Keputusan Gubernur Jawa Tengah. 2017. Keputusan Gubernur No.560/94 Tahun 2017 Tentang Upah Minimum pada 35 Kabupaten/ Kota di Provinsi Jawa Tengah tahun 2018. Semarang: Gubernur Jawa Tengah.

Kusnadi. 2000. Nelayan: Strategi Adaptasi dan Jaringan Sosial. Bandung: Humaniora Utama Press.

Lekatompessy HS, Nessa MN, Arief AA. 2013. Strategi Adaptasi Nelayan PulauPulau Kecil terhadap Perubahan Ekologis. Makassar: Universitas 
Hasanudin.

Manoppo VEN, Simbolon D, Tarumingkeng RC. Nikijuluw VPH. 2012. Mobilitas dan Alih Status Nelayan Skala Kecil di Provinsi Sulawesi Utara. Buletin PSP. 20(3): 239-247.

Miftahudin. 2016. Tingkat Pemanfaatan dan Pola Musim Udang Dogol (Metapenaeus ensis) Hasil Tangkapan Trammel Net di Cilacap [Skripsi]. Bogor: Institut Pertanian Bogor.

Mustaruddin, Simbolon D, Khotib M. 2016. Pola Dinamis Penurunan Hasil Tangkapan Udang Akibat Pengendapan dan Limbah Industri di Kawasan Sagara Anakan. Mar Fish. 7(2): 125-136.

Nugraheni PWA. 2015. Dampak Perubahan Cuaca terhadap Produktivitas dan Pendapatan Nelayan Cantrang di PPP Asemdoyong, Pemalang, Jawa Tengah [Skripsi]. Bogor: Institut Pertanian Bogor.

Pariwono JI. 1996. Pengaruh EL Nino Southern Oscillation (ENSO) terhadap Hasil Tangkapan Ikan Indonesia. Bogor: Lembaga Penelitian dan Pengabdian kepada Masyarakat.

Patriana R, Satria A. 2013. Pola Adaptasi Nelayan terhadap Perubahan Iklim: Studi Kasus Nelayan Dusun Ciawitali, Desa Pamotan, Kecamatan Kalipucang, Kabupaten Ciamis, Jawa Barat. Jurnal Sosial Ekonomi Kelautan dan Perikanan. 8(1): 11-23.

Pratama DS, Gumilar I, Maulina I. 2012. Analisis Pendapatan Nelayan Tradisional Pancing Ulur di Kecamata Manggar, Kabupaten Belitung Timur.
J. Ilmu Perikanan dan Kelautan. 3(3): 107-116.

Priadana F, Bambang AN, Kurohman F. 2017. Analisis Pendapatan Nelayan Jaring Gondrong (Trammel Net) di Desa Siklayu, Kabupaten Batang, Jawa Tengah. J. Perikanan Tangkap. $1(1): 1-7$.

Rahmah NOI. 2016. Strategi Adaptasi Nelayan Pancing Ulur terhadap Perubahan Cuaca di PPP Sadeng, Kabupaten Gunungkidul, Yogyakarta [Skripsi]. Bogor: Institut Pertanian Bogor.

Sachoemar SI, Yanagi T, Aliah RS. 2012. Variability of Sea Surface Chlorophyll-a, Temperature, and Fish Catch within Indonesian Region Revealed By Satellite Data. Marine Resarch in Indonesia. 2(2): 75-87.

Satria A. 2009. Pesisir dan Laut untuk Rakyat. Bogor: IPB Press.

Syahrir M, Baskoro MS, Darmawan, Lubis E, Wiyono ES. 2010. Pola Musim Penangkapan Ikan Pelagis di Perairan Teluk Apar. J. Ilmu Perikanan Tropis. 13(1): 1-8.

Umar H. 2004. Metode Penelitian untuk Skripsi dan Thesis Bisnis. Jakarta: Rajawali Press.

Wiyono ES. 2001. Optimasi Manajemen Perikanan Skala Kecil di Teluk Pelabuhanratu, Jawa Barat [Disertasi]. Bogor: Institut Pertanian Bogor.

Wiyono ES. 2008. Strategi Adaptasi Nelayan Cirebon. J. Ilmu Pertanian Indonesia. 17(3): 1-6. 